\title{
Mechanical and Corrosion Properties of Mg-Based Alloys with Gd Addition
}

\author{
Aneta Kania *, Ryszard Nowosielski, Agnieszka Gawlas-Mucha and Rafał Babilas * \\ Institute of Engineering Materials and Biomaterials, Faculty of Mechanical Engineering, \\ Silesian University of Technology, Konarskiego 18a, 44-100 Gliwice, Poland; \\ ryszard.nowosielski@polsl.pl (R.N.); agnieszka.gawlas04@gmail.com (A.G.-M.) \\ * Correspondence: aneta.kania@polsl.pl (A.K.); rafal.babilas@polsl.pl (R.B.); \\ Tel.: +48-32-237-1936 (A.K.); +48-32-237-1897 (R.B.)
}

Received: 15 March 2019; Accepted: 28 May 2019; Published: 31 May 2019

check for updates

\begin{abstract}
Magnesium alloys with rare earth metals are very attractive materials for medical application because of satisfactory mechanical properties. Nevertheless, low corrosion resistance is an obstacle in the use of $\mathrm{Mg}$ alloys as resorbable orthopedic implants. The paper presents results of mechanical and corrosion properties of MgCa5-xZn1Gdx ( $\mathrm{x}=1,2$, and $3 \mathrm{wt}$. \%) alloys. Based on the microscopic observations it was stated that the studied alloys show a dendritic microstructure with interdendritic solute rich regions. The phase analysis reveals an occurrence of $\alpha-\mathrm{Mg}$ and $\mathrm{Mg}_{2} \mathrm{Ca}, \mathrm{Ca}_{2} \mathrm{Mg}_{6} \mathrm{Zn}_{3}$ phases that are thermodynamic predictions, and stated $\mathrm{Mg}_{26} \mathrm{Zn}_{59} \mathrm{Gd}_{7}$ phases in MgCa5-xZn1Gdx $\left(\mathrm{x}=1,2\right.$, and $3 \mathrm{wt}$. \%) alloys. The $\mathrm{Mg}_{26} \mathrm{Zn}_{59} \mathrm{Gd}_{7}$ phases are visible as lamellar precipitations along interdendritic regions. It was confirmed that an increase of $\mathrm{Gd}$ content from 1 to $3 \mathrm{wt}$. \% improves ultimate tensile $\left(\mathrm{R}_{\mathrm{m}}\right.$; from 74 to $\left.89 \mathrm{MPa}\right)$ and compressive strength $\left(\mathrm{R}_{\mathrm{c}}\right.$; from 184 to $\left.221 \mathrm{MPa}\right)$. Moreover, the studied alloys are active in Ringer's solution. They are characterized by an increase of corrosion potential ( $\left.\mathrm{E}_{\text {corr }}\right)$ of about $150 \mathrm{mV}$ in comparison with values of open circuit potential $\left(\mathrm{E}_{\mathrm{OCP}}\right)$. The best electrochemical parameters (e.g., corrosion current density, $i_{\text {corr }}$, polarization resistance, $R_{p}$, and $\left.\mathrm{E}_{\text {corr }}\right)$ were obtained for the MgCa3Zn1Gd2 alloy.
\end{abstract}

Keywords: Mg-based alloys; microstructure characterization; mechanical properties; electrochemical testing; immersion tests

\section{Introduction}

The scientific literature contains many publications on the use of magnesium, calcium, and their alloys as resorbable materials for medical purposes [1-10]. The materials used for biomedical implants should be characterized by an appropriate load bearing capacity, especially in the case of small implants, biocompatibility, good mechanical properties, lack of clotting tendencies, even the ability to recycle, and high corrosion resistance in the tissue environment [10-17]. It is not possible to design the perfect alloy that connects all the required parameters. The problem is the poor corrosion resistance of $\mathrm{Ca}$ and $\mathrm{Mg}$ alloys $[4,8,18]$. In this respect, it should be noted that the environmental influence on corrosion affects the application of Mg alloys [19]. The corrosion rate is slow, for example, in pure water, but it is significant in chloride solutions (e.g., Ringer's solution that simulates the physiological environment) and acid solutions [19-21]. Knowing and understanding magnesium corrosion rate in vivo is an important issue for an application of Mg alloys in medicine [22-28]. To understand the corrosion mechanism of magnesium alloys, it is important to know the corrosion mechanism of pure $\mathrm{Mg}[19,20,29]$. It is also necessary to take account of the influence of metallurgical factors on corrosion of Mg-based alloys (e.g., the reactivity of $\mathrm{Mg}$, the presence of second phases, the influence of surface films and the influence of alloying elements on corrosion protection) [19,23,24,30-35]. Some elements 
have a detrimental influence on the corrosion of $\mathrm{Mg}$ alloys. The impurities $(\mathrm{Ni}, \mathrm{Cu}, \mathrm{Co}$, and $\mathrm{Fe})$ significantly accelerated the corrosion of binary Mg alloys [25]. Thus, it is important to keep the tolerance limit of the impurity concentration $[20,21,23,25]$. The proper selection of alloying elements is a fundamental matter for resorbable alloys design. They have an essential influence on corrosion mechanism, especially in the case of films formation and hydrogen evolution [20]. The compounds formed during implant dissolution must not be toxic to the human body $[5,10-12,36]$. It is also important to know the correlation between the dissolution rate of the material [20] and its mechanical properties. Too fast of a degradation process of Mg-based implants can lead to the lack of implant integrity with a tissue and a lack of adequate implant products that accumulate too fast around the implant and consequently cause an inflammation in the human body.

Recently, some results of microstructure and mechanical property investigations of Gd-containing alloys have been reported [12-15,18,30-34,37-39]. Liu et al. [37] examined the Mg-4.58Zn-2.6Gd-0.18Zr alloy after different heat treatments. The as-cast alloy was composed of primary $\alpha-\mathrm{Mg},(\alpha-\mathrm{Mg}+$ $\mathrm{Mg}_{3} \mathrm{Zn}_{3} \mathrm{Gd}_{2}$ ) eutectic, $\mathrm{Mg}_{3} \mathrm{Zn}_{6} \mathrm{Gd}$ phase, and $\mathrm{Mg}_{3} \mathrm{Gd}$ particles within $\alpha-\mathrm{Mg}$. They stated that after a solution treatment at $505{ }^{\circ} \mathrm{C}$ for $16 \mathrm{~h}$ and an aging treatment at $220^{\circ} \mathrm{C}$ over $16 \mathrm{~h}$, changes in the microstructure of the alloy resulted in the improvement of mechanical properties. The microstructural evolution, phase constitution, and mechanical properties of Mg-5.5Zn-xGd ( $\mathrm{x}=0.8,2$, and $4 \mathrm{wt}$. \%) alloys after directional solidification were studied by Yang et al. [38]. They confirmed that an increase of $\mathrm{Gd}$ content from 0 to $2 \mathrm{wt}$. \% caused the increase of tensile strength $\left(\mathrm{R}_{\mathrm{m}}\right)$. Above $2 \mathrm{wt}$. \% of gadolinium the $R_{m}$ decreased. There is no doubt that microstructural parameters (e.g., grain size or phase distribution) and crystallographic orientation are significant in determining the corrosion behaviors of Mg alloys [21,40].

The article presents the results of microstructure, mechanical properties, and corrosion resistance investigations of quaternary MgCa5-xZn1Gdx ( $x=1,2$, and $3 \mathrm{wt}$. \%) alloys as potential candidates for orthopedic implants. The composition of studied alloys was designed due to high solid solution strengthening of Mg alloys with Gd [14,32,34] and the results were also presented by Zheng et al. [17]. The minor Gd addition (1-3 wt. \%) in Mg-based alloys was dictated by an increase of ultimate tensile strength and decrease of degradation rate. The authors [17] stated that the degradation rate decreased up to $7 \mathrm{wt}$. \% of gadolinium. Therefore, taking into consideration the above results, the authors intended to verify the effect of minor gadolinium addition (from 1 to $3 \mathrm{wt}$ \%) into $\mathrm{Mg}$-based alloys on the improvement of mechanical properties and corrosion resistance.

Implants prepared from magnesium alloys with calcium and zinc after implantation in the human body slowly undergo spontaneous resorption. The addition of Ca into Mg-based alloys causes the increase of their strength, hardness, and resorbability [32]. Zinc improves tensile strength and hardness. This element increases the tolerance limits of impurities in $\mathrm{Mg}$ alloys [21]. On the other hand, the addition of gadolinium improves the strength properties and reduces the effect of microporosity resulting from the shrinkage of magnesium alloys [34]. Besides the strength and ductility improvement of $\mathrm{Mg}$ alloys, $\mathrm{Gd}$ addition also improves the corrosion resistance. Magnesium, calcium, and zinc are biocompatible materials. In the case of gadolinium, there are not so many reports on its biocompatibility. It is known that $\mathrm{Gd}$ is characterized by a high solubility in solid $\mathrm{Mg}$ at eutectic temperatures [17], because of that it influences the reduction of intermetallic phases distribution and galvanic coupling formation. Therefore, $\mathrm{Mg}$ alloys with $\mathrm{Gd}$ addition are selected for biomedical alloys. Recently, some investigations of in vivo and in vitro studies with Gd-containing Mg alloys were carried out. Myrissa et al. [41] performed an in vitro qualitative analysis of cell distribution and viability of the binary Mg10Gd alloy. They stated that after 13 days of culture in a proliferative medium the viable cells on the studied alloy were revealed. Gadolinium added into Mg-based alloys may be a promising material to use in medicine, but there is a need for more in vivo and in vitro studies as well as clinical investigations.

The aim of the study is to investigate the hardness, tensile, and compressive properties of the alloys with minor addition of gadolinium (from 1 to $3 \mathrm{wt}$. \%) at the expense of decreasing calcium 
content. Moreover, the evaluation of corrosion resistance of the Mg-based alloys with Gd is also a complementary purpose of the investigations.

\section{Materials and Methods}

The research materials included three magnesium-based alloys in as-cast state: MgCa4Zn1Gd1, MgCa3Zn1Gd2, and MgCa2Zn1Gd3.

Mg-based alloys were prepared by induction melting in an argon atmosphere with technical purity (99.9\%). Pure magnesium (99.99\%) in the form of ingots, zinc in the form of rods $(99.99 \%$ pure), calcium ( $99.5 \%$ pure), and gadolinium granules (99.9\% pure) were melted in chamotte-graphite crucibles. The molten ingots were homogenized by annealing over $30 \mathrm{~min}$ at the temperature of $750{ }^{\circ} \mathrm{C}$. The molten alloys were cast into sand molds hardened with a polymer (FIBRAL). The obtained plates had dimensions of $100 \mathrm{~mm} \times 280 \mathrm{~mm} \times 14 \mathrm{~mm}$.

\subsection{Structure Testing and Phase Analysis}

The microstructure of studied alloys was observed on transverse microsections in the Zeiss SUPRA 35 scanning electron microscope (SEM, Thornwood, New York, NY, USA); extra-high tension $(\mathrm{EHT})=20.00 \mathrm{kV}$; working distance $(\mathrm{WD})=10.5 \mathrm{~mm}$, backscattered electrons (BSE) mode equipped with an energy-dispersive $\mathrm{X}$-ray spectrometer (EDS).

The microstructure was also observed by a high-resolution transmission electron microscope S/TEM TITAN 80-300 FEI (Hillsboro, OR, USA) equipped with a Cs-corrector. The investigations with an acceleration voltage of $300 \mathrm{kV}$ were performed. The high-resolution transmission electron microscope (HRTEM) images and selected area electron diffraction (SAED) patterns were collected. Scanning transmission electron microscope (STEM) imaging was performed using a high-angle annular dark field (HAADF) detector that allowed us to distinguish a difference in the value as a result of the difference in scattering. Electron beam with a convergence semi-angle of 17 and $27 \mathrm{mrad}$ was used. Samples for observations were prepared by gallium ion milling.

The phase analysis of the samples was carried out in the PANalytical X-ray diffractometer ( $X^{\prime}$ Pert PRO model, Almelo, The Netherlands) using the Co K $\alpha$ radiation (with a wavelength of $0.1789 \mathrm{~nm}$ ). The measurements using the step registration method in the angular $2 \theta$ range from $30^{\circ}$ to $90^{\circ}$ were conducted. The X-ray qualitative analysis was performed using the HighScore Plus software (3.0e version, PANalytical, Almelo, The Netherlands).

\subsection{Mechanical Tests}

The tensile and compressive tests were carried out at room temperature with the ZWICK Z100 static material testing machine (Kennesaw, GE, USA) according to the standards [42,43]. The cylindrical samples with working diameters of $5 \mathrm{~mm}$ and lengths of $90 \mathrm{~mm}$ were prepared for tensile tests [42]. A pre-load force during the test was $2 \mathrm{~N}$ and the strain rate was $0.0067 \mathrm{~s}^{-1}$. The samples for static compression tests had diameters of $10 \mathrm{~mm}$ and heights of $15 \mathrm{~mm}$ [43]. A pre-load force of $2 \mathrm{~N}$ and beam move speed of $100 \mathrm{~mm} \cdot \mathrm{min}^{-1}$ were assumed. The Vickers hardness tests were performed with the Future-Tech FM-ARS 9000 device (Kawasaki, Kanagawa, Japan) under the load of 1 N. For each studied alloy 10 measurements were performed.

\subsection{Electrochemical and Immersion Tests}

The electrochemical and immersion tests were performed in Ringer's solution at $37^{\circ} \mathrm{C}$. The Ringer's solution simulates the physiological environment of a human body. The electrochemical tests were carried out using the Autolab PGSTAT302N Multi BA potentiostat (Herisau, Switzerland). The open circuit potential $\left(\mathrm{E}_{\mathrm{OCP}}\right)$ measurements and the potentiodynamic tests were carried out. The measurements were performed in a three-electrode cell with a water jacket using a saturated calomel electrode (SCE) as a reference electrode, a platinum rod as a counter electrode, and a sample as working electrode. The corrosion potential scan rate was $1 \mathrm{mV} \cdot \mathrm{s}^{-1}$. In case of corrosion tests, changes 
of the open circuit potential as a function of $3600 \mathrm{~s}$ were collected. The exposure for the corrosion environment during immersion tests was $48 \mathrm{~h}$.

The cylindrical samples with a testing area of $1.1 \mathrm{~cm}^{2}$ were prepared for electrochemical tests. The orifice of the sample holder had a diameter of $10 \mathrm{~mm}$. For immersion tests, rectangular samples with dimensions of $5.9 \mathrm{~mm} \times 5.9 \mathrm{~mm} \times 17.5 \mathrm{~mm}$ were prepared. The basic corrosion parameters of the studied alloys were determined using the Tafel's analysis. The corrosion rate, $\mathrm{v}_{\text {corr }}$, based on the corrosion current density ( $\mathrm{i}_{\text {corr }}$ ) value was also calculated. The hydrogen evolution volume was measured and calculated taking into account a surface of the samples. After immersion tests the corroded surface with corrosion products for each of the samples was observed by the SEM method; the investigation was carried out on gold sputtered samples. Additionally, the samples surface without corrosion products was observed using a Zeiss SteREO Discovery stereoscopic microscope (Thornwood, New York, NY, USA). The samples were rinsed with distilled water and immersed in $\mathrm{CrO}_{3}$ solution before microscopic observations.

\section{Results and Discussion}

The results of the phase analysis allowed us to identify $\alpha-\mathrm{Mg}$ and $\mathrm{Mg}_{2} \mathrm{Ca}, \mathrm{Ca}_{2} \mathrm{Mg}_{6} \mathrm{Zn}_{3}$, and $\mathrm{Mg}_{26} \mathrm{Zn}_{59} \mathrm{Gd}_{7}$ intermetallic phases in MgCa5-xZn1Gdx ( $\mathrm{x}=1,2$, and $3 \mathrm{wt}$. \%) alloys (Figure 1). The $\alpha-\mathrm{Mg}, \mathrm{Mg}_{2} \mathrm{Ca}$, and $\mathrm{Ca}_{2} \mathrm{Mg}_{6} \mathrm{Zn}_{3}$ phases are in agreement with the phase equilibrium diagram and the following works [2,14,32]. The detected $\mathrm{Mg}_{26} \mathrm{Zn}_{59} \mathrm{Gd}_{7}$ phases are a part of the finding [44]. It can be observed that a decrease of Ca content in the alloys with Gd addition leads to the formation of a low volume of $\mathrm{Mg}_{2} \mathrm{Ca}$ and $\mathrm{Ca}_{2} \mathrm{Mg}_{6} \mathrm{Zn}_{3}$ secondary phases. Moreover, the addition of Gd up to $2 \mathrm{wt}$. \% caused only a slight increase of $\mathrm{Mg}_{26} \mathrm{Zn}_{59} \mathrm{Gd}_{7}$ phases volume. Above this concentration no visible changes in the microstructure were observed.

All detected $\mathrm{Mg}_{26} \mathrm{Zn}_{59} \mathrm{Gd}_{7}, \mathrm{Ca}_{2} \mathrm{Mg}_{6} \mathrm{Zn}_{3}$, and $\mathrm{Mg}_{2} \mathrm{Ca}$ phases with a hexagonal microstructure belong to the same space group of $\mathrm{P} 63 / \mathrm{mmc}$. The Gd-containing compounds have following lattice parameters: $\mathrm{a}=14.633 \AA, \mathrm{b}=14.633 \AA$, and $\mathrm{c}=8.761 \AA$ [44]. These lamellar phases with lengths of about $100 \mathrm{~nm}$ are distributed along the interdendritic regions (Figure 2).

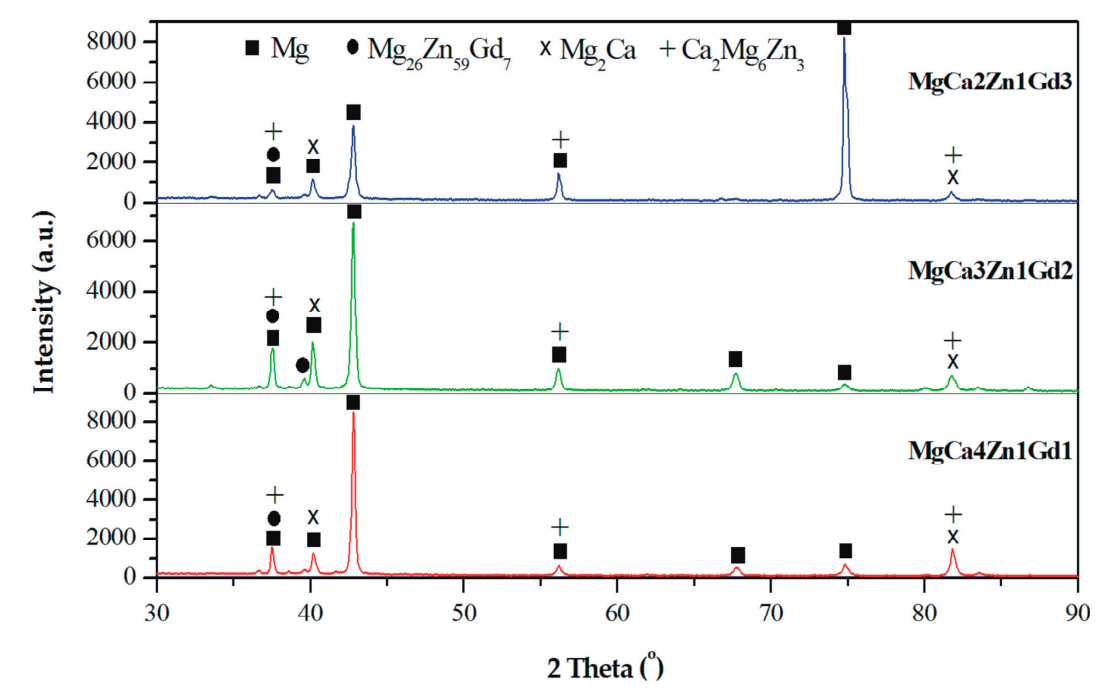

Figure 1. X-ray diffraction patterns of MgCa5-xZn1Gdx ( $x=1,2$, and 3 wt. \%) alloys.

The as-cast MgCa5-xZn1Gdx ( $x=1,2$, and $3 \mathrm{wt}$. \%) alloys show a dendritic microstructure with interdendritic solute rich regions. The microstructure of the studied alloys is composed of a primary $\alpha-\mathrm{Mg}$ phase and $\left(\alpha-\mathrm{Mg}+\mathrm{Mg}_{2} \mathrm{Ca}\right),\left(\alpha-\mathrm{Mg}+\mathrm{Mg}_{2} \mathrm{Ca}+\mathrm{Ca}_{2} \mathrm{Mg}_{6} \mathrm{Zn}_{3}\right)$, and $\left(\alpha-\mathrm{Mg}+\mathrm{Mg}_{26} \mathrm{Zn}_{59} \mathrm{Gd}_{7}\right)$ eutectics that are distributed at grain boundaries (Figure 3). It can be observed that the eutectics volume decreases with the addition of gadolinium. This is because of the low volume of $\mathrm{Mg}_{2} \mathrm{Ca}$ and $\mathrm{Ca}_{2} \mathrm{Mg}_{6} \mathrm{Zn}_{3}$ intermetallic phases that fill more space among the grain boundaries. Moreover, it can be 
observed that Gd-containing phases distributed along interdendritic regions appear as bright areas (Figures 2 and 4) [30].

The microstructure of Mg-based alloy with $22 \mathrm{wt}$. \% Gd addition was observed by Vlcek et al. [20]. After microscopic observations they confirmed that the Mg22Gd alloy exhibits a dendritic microstructure with $\mathrm{Mg}_{46} \mathrm{Gd}_{9}$ intermetallic phase formed in grain boundaries [12]. Shi et al. [14] examined a microstructure of Mg-10Gd-xCa- $0.5 \mathrm{Zr}(\mathrm{x}=0,0.3$, and $1.2 \mathrm{wt}$. \%) alloys and stated that the $\mathrm{Mg}_{5} \mathrm{Gd}$ phase in the form of bright particles in the $\alpha$-Mg matrix was also detected.

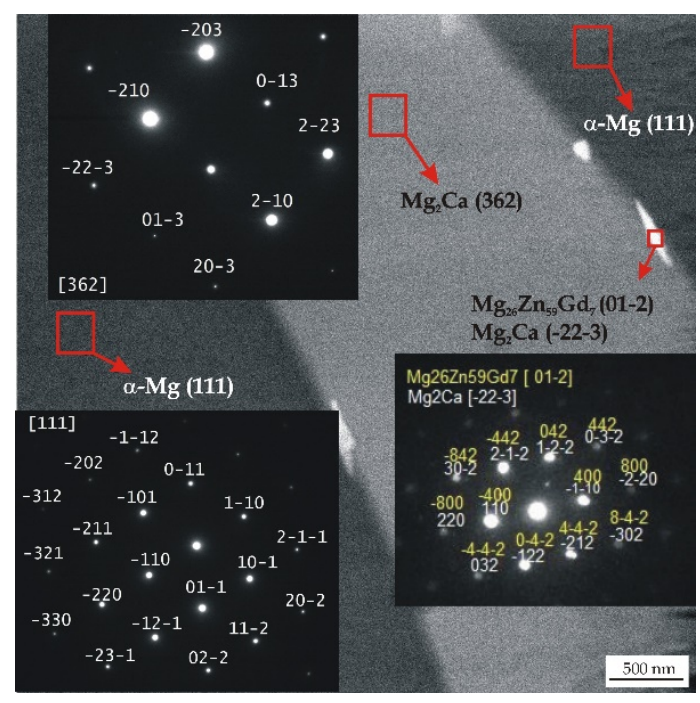

Figure 2. TEM micrograph and corresponding selected area electron diffraction (SAED) patterns from selected areas of the MgCa2Zn1Gd3 alloy.

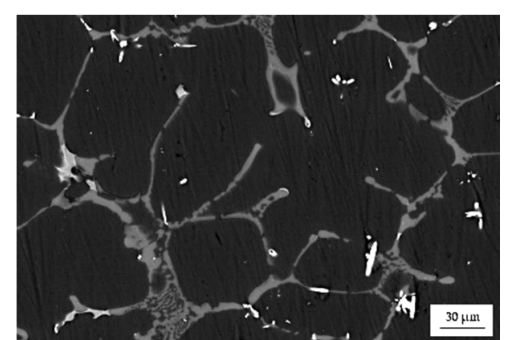

(a)

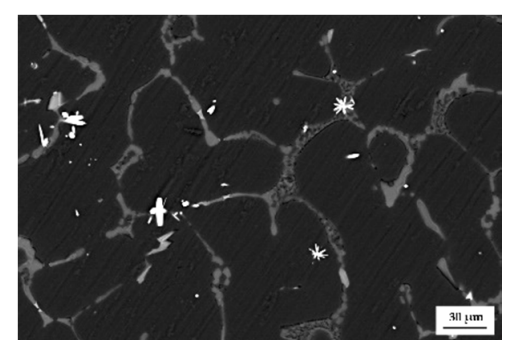

(b)

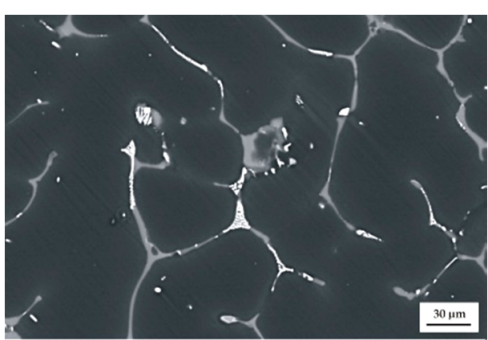

(c)

Figure 3. SEM images of: (a) MgCa4Zn1Gd1; (b) MgCa3Zn1Gd2; and (c) MgCa2Zn1Gd3 alloys.

The SEM images and corresponding EDS spectra (Figure 4) of the MgCa3Zn1Gd2 alloy indicated a formation of the eutectic area (interdendritic region). The region that consists of $\mathrm{Mg}$ and the highest $\mathrm{Ca}$ than $\mathrm{Zn}$ concentration is related to $\mathrm{Mg}_{2} \mathrm{Ca}$ phase (Figure 4a). The area composed of $\mathrm{Mg}, \mathrm{Ca}, \mathrm{Zn}$, and $\mathrm{Gd}$ indicated the $\mathrm{Mg}_{26} \mathrm{Zn}_{59} \mathrm{Gd}_{7}$ phases' formation (Figure $4 \mathrm{~b}$ ). Moreover, the last region where $\mathrm{Mg}, \mathrm{Ca}$, and $\mathrm{Zn}$ elements were detected with EDS method belongs to $\mathrm{Mg}_{2} \mathrm{Ca}$ and $\mathrm{Ca}_{2} \mathrm{Mg}_{6} \mathrm{Zn}_{3}$ intermetallic phases (Figure 4c).

The results of mechanical tests indicated that tensile properties are improved with gadolinium addition. The selected tensile curves of the studied alloys are shown in Figure 5. The differences in the mechanical behavior can be observed. The improvement of tensile properties as a function of gadolinium addition is due to the solid solution strengthening and precipitation hardening caused by high solubility of $\mathrm{Gd}$ in $\mathrm{Mg}$ at eutectic temperatures [17,34]. The tensile properties of MgCa5-xZn1Gdx $(\mathrm{x}=1,2$, and $3 \mathrm{wt}$. \%) alloys at room temperature are also summarized in Table 1 . The ultimate tensile strength $\left(\mathrm{R}_{\mathrm{m}}\right)$ equal to $89 \mathrm{MPa}( \pm 3.6 \mathrm{SD} ; \pm 6.8 \mathrm{CI})$ was obtained for the MgCa2Zn1Gd3 alloy. The $\mathrm{R}_{\mathrm{m}}$ of the MgCa4Zn1Gd1 and MgCa3Zn1Gd2 alloys are $74 \mathrm{MPa}( \pm 3.0 \mathrm{SD} ; \pm 5.7 \mathrm{CI})$ and $78 \mathrm{MPa}( \pm 1.9 \mathrm{SD}$; $\pm 3.5 \mathrm{CI}$ ), respectively (Figure 6). 


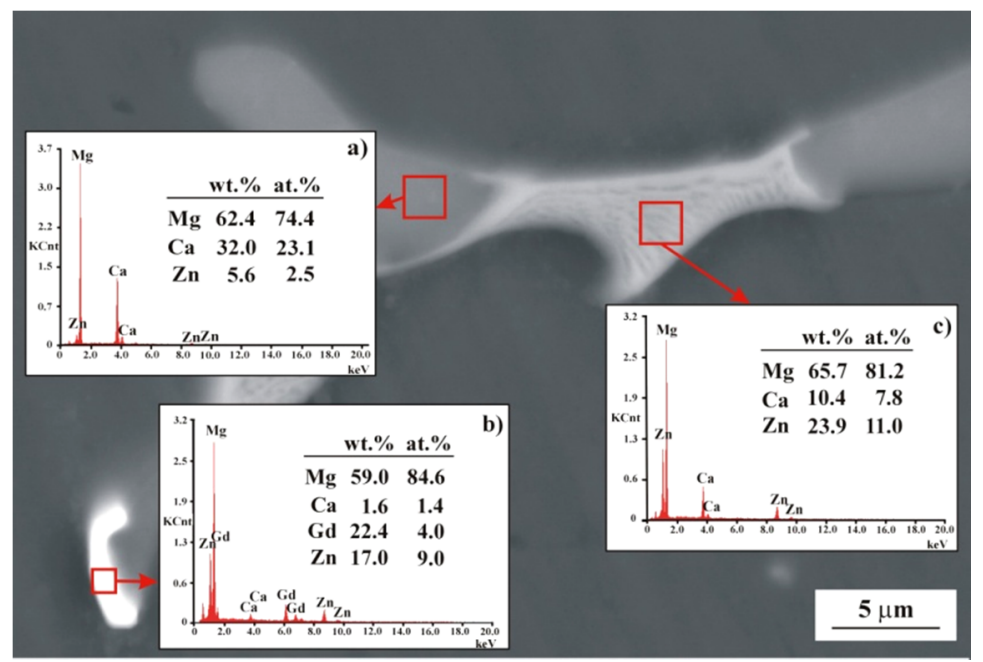

Figure 4. SEM image of MgCa3Zn1Gd2 alloy with EDS spectra $(\mathbf{a}-\mathbf{c})$ from selected areas.

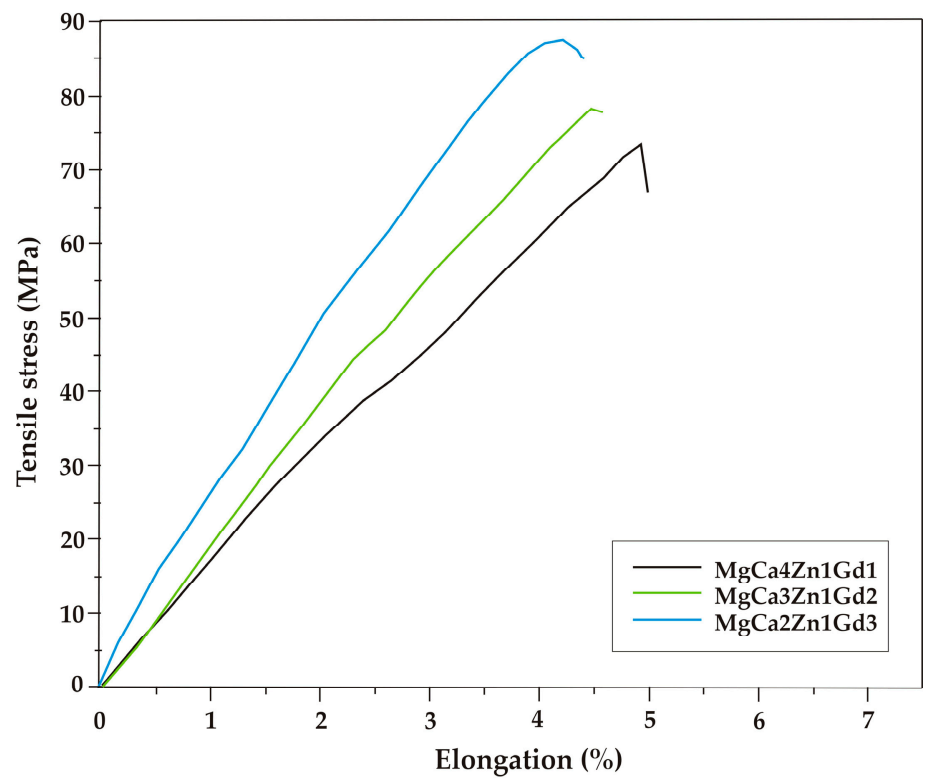

Figure 5. Tensile stress-elongation curves for the $\mathrm{Mg}$ alloys with $\mathrm{Gd}$ addition.

Table 1. Values of static tensile tests of MgCa5-xZn1Gdx ( $x=1,2$, and 3 wt. \%) alloys.

\begin{tabular}{cccc}
\hline Alloy & $\begin{array}{c}\text { Tensile Yield Strength, } \\
\text { YTS, MPa }\end{array}$ & $\begin{array}{c}\text { Ultimate Tensile Strength, } \\
\mathbf{R}_{\mathbf{m}}, \mathbf{M P a}\end{array}$ & $\begin{array}{c}\text { Maximum Elongation, } \\
\mathbf{A}_{\mathbf{t}}, \mathbf{\%}\end{array}$ \\
\hline MgCa4Zn1Gd1 & $40 \pm 1.7$ & 74 & 4.8 \\
MgCa3Zn1Gd2 & $42 \pm 2.4$ & 78 & 4.4 \\
MgCa2Zn1Gd3 & $48 \pm 2.9$ & 89 & 4.2 \\
\hline
\end{tabular}

The addition of gadolinium to the $\mathrm{Mg}$ alloys leads to an enhancement of yield strength. The values of tensile yield strength (YTS) increased from 40 to $48 \mathrm{MPa}$. These results were confirmed by mechanical investigations reported by Zheng et al. [15], Zheng et al. [17] and Gao et al. [34]. The values of tensile yield strength are comparable to YTS obtained for Mg-4Zn-2Gd-1Ca alloy by Wen et al. [36]. The tensile yield strength reached a value of $44 \mathrm{MPa}$ for the studied alloy. Moreover, it can be observed that the addition of gadolinium to the $\mathrm{Mg}$ alloys causes a decrease of the elongation (from $4.8 \%$ to $4.2 \%$ ). The improvement of the ultimate tensile strength and a decrease of the elongation with an increase of Gd content in the Mg alloys were observed by Zheng et al. [17] and Li et al. [45], respectively. 
The obtained results indicated that the addition of Gd into Mg-based alloys and the formation of Gd-containing phases caused the enhancement of strength (ultimate and tensile yield strength). A slight improvement of tensile properties of the alloys with 2 and $3 \mathrm{wt}$. \% Gd was an effect of a low volume of hard $\mathrm{Mg}_{2} \mathrm{Ca}$ and $\mathrm{Ca}_{2} \mathrm{Mg}_{6} \mathrm{Zn}_{3}$ intermetallic phases formed along the grain boundaries. They caused embrittlement of $\mathrm{Mg}$ alloys [46]. Much higher tensile values compared with the studied $\mathrm{Mg}-\mathrm{Ca}-\mathrm{Zn}-\mathrm{Gd}$ alloys could be obtained after heat treatment and plastic forming. Rare earth metals can improve the mechanical properties, high temperature strength and creep resistance of Mg-based alloys [13-15,18,30-32]. Liu et al. [31] examined the Mg1.5Zn0.2Gd alloy, which was rolled at $450{ }^{\circ} \mathrm{C}$ and annealed at $350^{\circ} \mathrm{C}$. They stated that tensile strength of the alloy was above $200 \mathrm{MPa}$ [31].

The results of tensile tests were complemented by the fracture morphologies of the studied $\mathrm{Mg}$ alloys after tensile failure (Figure 7). The fractures of the alloys manifested ductile and fragile behaviors. Some sharp edges, cleavages, areas of shallow dimples, and fatigue cracks (with lengths up to $130 \mu \mathrm{m}$ ) could be seen in the SEM images. The fractures were also characterized with intergranular fracture along the grain boundaries. This is a reason of a decrease in elongation with the increase of Gd content.

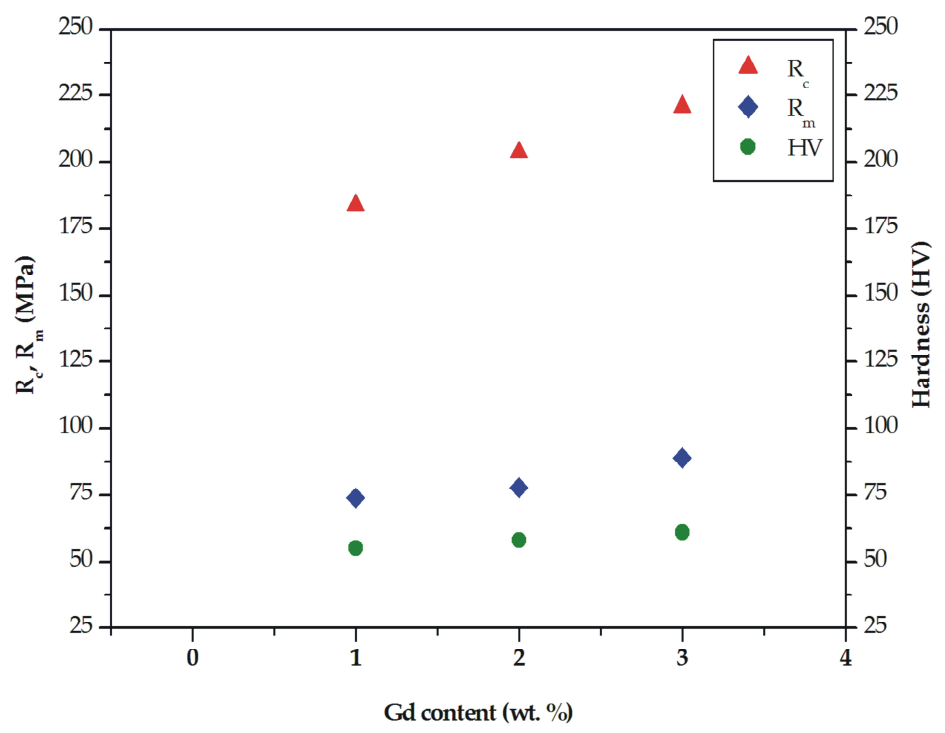

Figure 6. Ultimate tensile strength $\left(R_{m}\right)$, compressive strength $\left(R_{c}\right)$, and Vickers hardness for MgCa5-xZn1Gdx ( $x=1,2$, and 3 wt. \%) alloys.

The fracture morphologies of Gd-containing alloys were in agreement with the fracture morphologies obtained for Mg-4Zn-2Gd-0.2Ca and Mg-4Zn-2Gd-1Ca alloys. Wen et al. [36] stated that the fracture surface of the $\mathrm{Mg}-4 \mathrm{Zn}-2 \mathrm{Gd}-1 \mathrm{Ca}$ alloy is also characterized by intergranular fracture. They noticed that the precipitated phases are mainly distributed in interdendritic regions [36].

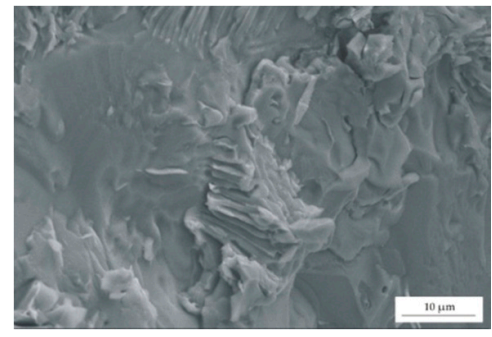

(a)

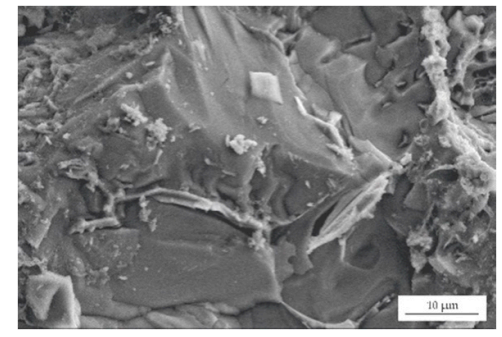

(b)

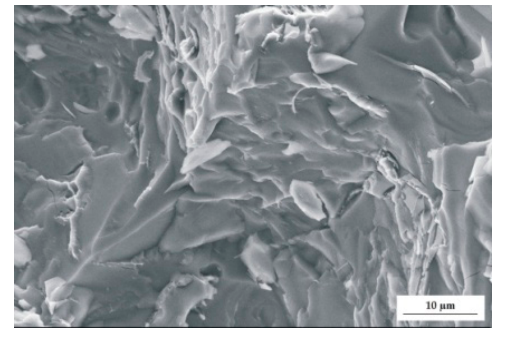

(c)

Figure 7. SEM images of selected regions of the fracture surface for: (a) MgCa4Zn1Gd1; (b) MgCa3Zn1Gd2; and (c) MgCa2Zn1Gd3.

The improvement of mechanical properties was also observed for the compressive results. The compressive strength $\left(R_{c}\right)$ of the studied alloys was $184 \mathrm{MPa}( \pm 3.0 \mathrm{SD} ; \pm 5.7 \mathrm{CI}), 204 \mathrm{MPa}( \pm 3.8 \mathrm{SD}$; 
$\pm 7.1 \mathrm{CI})$, and $221 \mathrm{MPa}( \pm 4.1 \mathrm{SD} ; \pm 7.8 \mathrm{CI})$ for the Mg alloys with 1,2 , and $3 \mathrm{wt} . \% \mathrm{Gd}$, respectively (Figure 6). The compressive parameters at room temperature of MgCa5-xZn1Gdx ( $x=1,2$, and $3 \mathrm{wt}$. $\%)$ alloys are listed in Table 2.

It can be noticed that the addition of $\mathrm{Gd}$ into Mg alloys has an effect on the increase of compressive values (compressive yield strength increased from 120 to $135 \mathrm{MPa}$ and compressive strain was improved from $7 \%$ to $9 \%$ ). Improved strength properties of the studied alloys with 2 and $3 \mathrm{wt}$. \% Gd are related to the improvement of microstructure by a high volume of $\mathrm{Mg}_{26} \mathrm{Zn}_{59} \mathrm{Gd}_{7}$ phases distributed along grain boundaries and a low volume of brittle $\mathrm{Mg}_{2} \mathrm{Ca}$ phases. High compression parameters were obtained for $\mathrm{Mg}_{94} \mathrm{Zn}_{3} \mathrm{Y}_{1.5} \mathrm{Gd}_{1.5}$ alloy. Shi et al. [39] stated that compressive stress, compressive yield stress, and compression ratio of this alloy are $414 \mathrm{MPa}, 230 \mathrm{MPa}$, and $18.2 \%$, respectively.

Table 2. Values of static compressive tests of MgCa5-xZn1Gdx ( $x=1,2$, and 3 wt. \%) alloys.

\begin{tabular}{cccc}
\hline Alloy & $\begin{array}{c}\text { Compressive Yield Strength, } \\
\text { YCS, } \mathbf{M P a}\end{array}$ & $\begin{array}{c}\text { Compressive Strength, } \\
\mathbf{R}_{\mathbf{c}}, \mathbf{M P a}\end{array}$ & $\begin{array}{c}\text { Compressive Strain, } \\
\mathbf{\%}\end{array}$ \\
\hline MgCa4Zn1Gd1 & $120 \pm 4.6$ & 184 & $7.0 \pm 1.1$ \\
MgCa3Zn1Gd2 & $130 \pm 3.9$ & 204 & $8.5 \pm 0.9$ \\
MgCa2Zn1Gd3 & $135 \pm 5.1$ & 221 & $9.0 \pm 1.3$ \\
\hline
\end{tabular}

The tensile and compressive properties are complemented by hardness tests. The results of the Vickers hardness indicated that the increase of the gadolinium addition has a slight effect on the hardness changes. The hardness of the studied alloys was improved from $55 \mathrm{HV} 1( \pm 2.9 \mathrm{SD} ; \pm 2.5 \mathrm{CI})$ for the alloy with $1 \mathrm{wt}$. \% Gd content to $61 \mathrm{HV} 1( \pm 5.6 \mathrm{SD} ; \pm 4.9 \mathrm{CI})$ for the alloy with $3 \mathrm{wt} . \% \mathrm{Gd}$. The hardness of the MgCa3Zn1Gd2 alloy was 58 HV1 ( \pm 4.4 SD; $\pm 3.8 \mathrm{CI}$; Figure 6). It could be assumed that the increase of hardness obtained for the alloy with the highest $\mathrm{Gd}$ content was caused by a decrease of eutectic volume. The similar hardness, equaled $59 \mathrm{HV}$, was obtained for Mg-Gd-2Nd-0.5Zr alloy in an as-cast state [15].

The slight improvement of mechanical properties is not enough to select the magnesium alloys for medical application. An important issue is the corrosion resistance of $\mathrm{Mg}$ alloys that are very active in a physiological environment $[10,11,14,39,46]$. Many methods can be used to measure corrosion rates of the $\mathrm{Mg}$ alloys. The corrosion rate can be evaluated from the evolved $\mathrm{H}_{2}$ volume, Tafel's extrapolation of polarization curves and electrochemical impedance spectroscopy (EIS) [26]. In the present study the corrosion parameters (e.g., corrosion rates) were measured using Tafel's extrapolation of polarization curves and the evolved hydrogen volume.

The measurement of the open circuit potential $\left(\mathrm{E}_{\mathrm{OCP}}\right)$ changes was used to evaluate the protective properties of layers, which are formed on the surface of alloys exposed to the corrosive environment. It should be noticed that the oxide layer formed on the surface of Mg-based alloys is leaky without a protective barrier. The tightness of oxide layers describes the Pilling-Bedworth ratio, which for $\mathrm{Mg}$ alloys is less than 1 . There are two types of surface films formed on the Mg during corrosion. In chloride solutions a thin layer of $\mathrm{MgO}$ is covered by a loose layer of $\mathrm{Mg}(\mathrm{OH})_{2}$ [19]. Both layers exhibit limited protective behaviors. The film formed during preparation of samples is degraded in an initial stage of immersion. At the same time, the second film is formed on the corroding surface of magnesium. To understand the corrosion mechanism of surface layers, X-ray photoelectron spectroscopy (XPS) is often used. This is a technique for a quantitative analysis of chemical changes that occur on the surface of $\mathrm{Mg}$ alloys [29]. Finally, it should be noted that the $\mathrm{pH}$ of the solution dependent on corrosion is related to the surface films that are formed on $\mathrm{Mg}$ in various solutions $[19,20,23,24,27,28,47]$. The $\mathrm{pH}$ increases rapidly in the first hours of immersion to a $\mathrm{pH}$ of $\sim 10.3$ due to a low solubility of $\mathrm{Mg}(\mathrm{OH})_{2}$. This is a significant issue in a corrosion study of $\mathrm{Mg}$ alloys for medical application [27]. Human blood has a $\mathrm{pH}$ of $\sim 7.4$. It is mainly regulated by the lungs through respiration influencing the rate of $\mathrm{CO}_{2}$ removal from the blood. The best practice in studying $\mathrm{Mg}$ corrosion is to use a large solution volume and take the same $\mathrm{CO}_{2}$-bicarbonate buffer as in the body $[27,28]$. 
The curves determined for a stationary potential as a function of time indicate that all $\mathrm{Mg}$ alloys are active in a corrosive environment. However, the MgCa2Zn1Gd3 alloy shows a higher activity in Ringer's solution than the other tested alloys (Figure 8).

The values of $\mathrm{E}_{\mathrm{OCP}}$ potential are related to a composition of the studied alloys. The increase of gadolinium content causes a slight increase of the open circuit potential. The small differences of the $\mathrm{E}_{\mathrm{OCP}}$ potential among Gd-containing alloys are from minor changes of the chemical composition. These changes are not higher than $40 \mathrm{mV}$ after $3600 \mathrm{~s}$. Moreover, it can be observed that cathodic polarization shifts the corrosion potential ( $E_{\text {corr }}$ ) towards positive values (Figure 9).

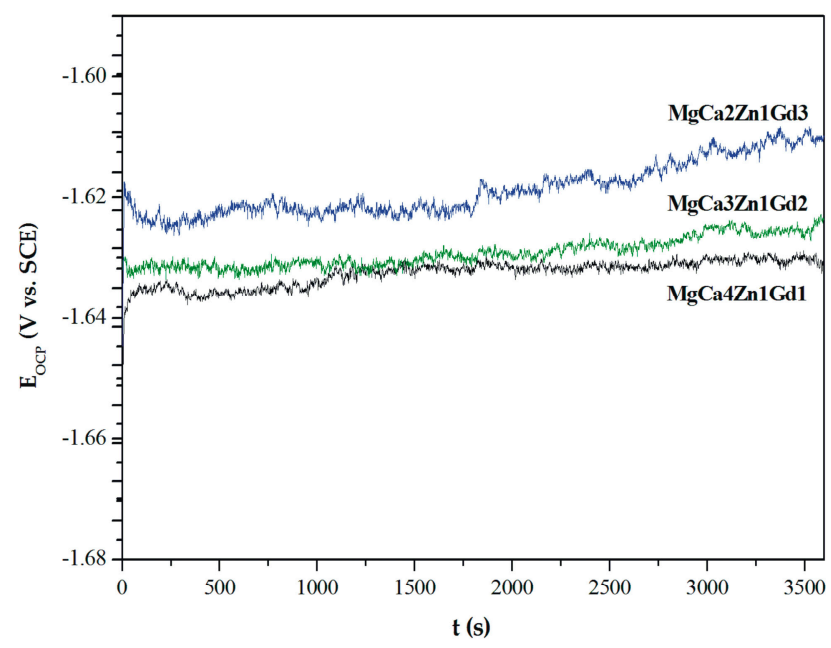

Figure 8. The open circuit potential $\left(\mathrm{E}_{\mathrm{OCP}}\right)$ changes as a function of time for studied MgCa5-xZn1Gdx $(x=1,2$, and 3 wt. $\%)$ alloys in Ringer's solution at $37^{\circ} \mathrm{C}$.

The increase of the corrosion potential (about $150 \mathrm{mV}$ for the MgCa3Zn1Gd2; $\mathrm{E}_{\mathrm{OCP}}$ for the alloy was about $-630 \mathrm{mV}$ and $\mathrm{E}_{\text {corr }}$ was $-1480 \mathrm{mV}$ ), suggests that the studied alloys exhibited quite good corrosion resistance. These changes resulted from the reduction of gadolinium oxides.

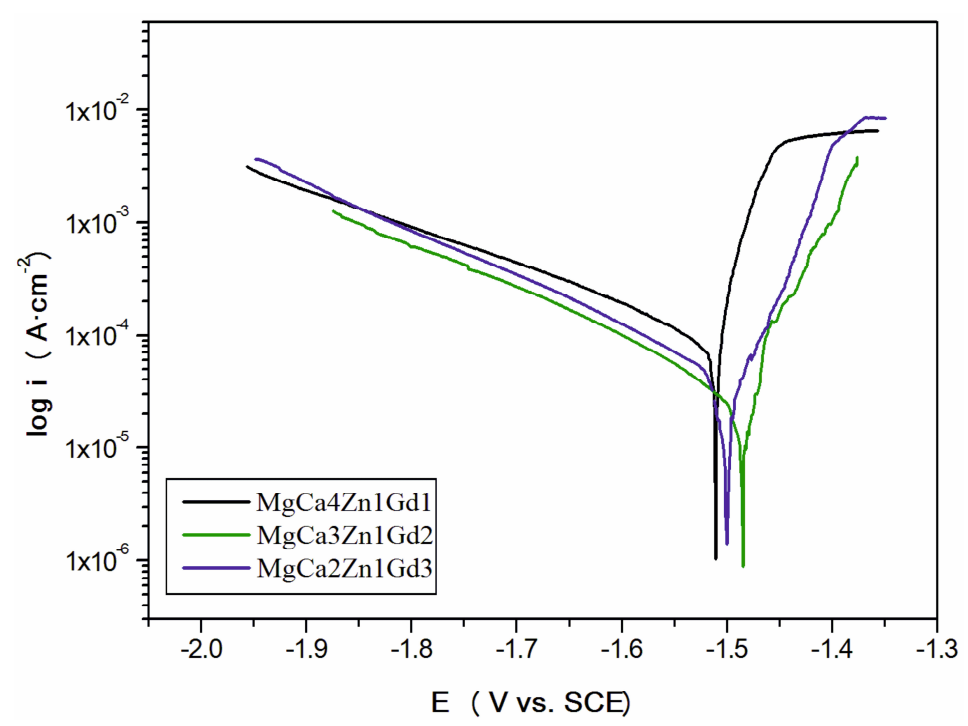

Figure 9. Polarization curves for MgCa5-xZn1Gdx ( $x=1,2$, and 3 wt. \%) alloys in Ringer's solution at $37^{\circ} \mathrm{C}$.

Extrapolation of polarization curves using Tafel's method allowed us to determine the polarization resistance $\left(R_{p}\right)$ and corrosion current density ( $\left.i_{\text {corr }}\right)$ of the studied alloys (Table 3$)$. 
The polarization curves provided some useful information to recognize the $\mathrm{Mg}$ corrosion mechanism. It can be also noticed that for Mg alloys, Tafel's extrapolation of polarization curves gives corrosion rate values that typically do not agree with weight loss or hydrogen evolution $[19,22,23,27]$. In many reports $[22,23]$ we can find that Tafel's extrapolation can be used to measure an initial corrosion behavior that does not correlate with a real, steady state of corrosion behavior. The lowest value of $i_{\text {corr, }}$ equaled $51 \mu \mathrm{A} \cdot \mathrm{cm}^{-2}$, and the highest polarization resistance, $R_{p}$, equaled $532 \Omega \cdot \mathrm{cm}^{2}$, were observed for the MgCa3Zn1Gd2 alloy. A good corrosion resistance of this alloy confirmed a value of corrosion rate, $\mathrm{v}_{\text {corr }}$, which equals $0.62 \mathrm{~mm} \cdot \mathrm{y}^{-1}$. A significant deterioration of the corrosion resistance indicates the alloy with $1 \mathrm{wt}$. \% Gd content. The corrosion current density for this alloy was higher and it was $170 \mu \mathrm{A} \cdot \mathrm{cm}^{-2}\left(\mathrm{R}_{\mathrm{p}}\right.$ was $\left.110 \Omega \cdot \mathrm{cm}^{2}\right)$. MgCa4Zn1Gd1 was characterized by the highest corrosion rate $\left(\mathrm{v}_{\text {corr }}\right.$ was $\left.1.86 \mathrm{~mm} \cdot \mathrm{y}^{-1}\right)$. This is because of a high Ca content. A high volume of $\mathrm{Mg}_{2} \mathrm{Ca}$ phases significantly accelerates anodic kinetics of magnesium [39]. A further increase of the gadolinium content caused a slight increase of corrosion current density ( $\mathrm{i}_{\text {corr }}$ for the alloy with $3 \mathrm{wt}$. \% Gd was $98 \mu \mathrm{A} \cdot \mathrm{cm}^{-2}$ ). The corrosion rate of the MgCa2Zn1Gd3 alloy was $1.48 \mathrm{~mm} \cdot \mathrm{y}^{-1}$.

Table 3. Corrosion parameters of MgCa5-xZn1Gdx ( $x=1,2$, and 3 wt. \%) alloys.

\begin{tabular}{ccccc}
\hline Alloy & $\begin{array}{c}\text { Corrosion Potential, } \\
\mathbf{E}_{\mathbf{c o r r}}, \mathbf{V}\end{array}$ & $\begin{array}{c}\text { Polarization Resistance, } \\
\mathbf{R}_{\mathbf{p}}, \mathbf{\Omega} \cdot \mathbf{c m}^{\mathbf{2}}\end{array}$ & $\begin{array}{c}\text { Corrosion Current Density, } \\
\mathbf{i}_{\text {corr }} \boldsymbol{\mu} \mathbf{\mu} \mathbf{A} \cdot \mathbf{c m}^{-\mathbf{2}}\end{array}$ & $\begin{array}{c}\text { Corrosion Rate, } \\
\mathbf{v}_{\mathbf{c o r r}}, \mathbf{m m} \cdot \mathbf{y}^{\mathbf{- 1}}\end{array}$ \\
\hline MgCa4Zn1Gd1 & $-1.51 \pm 0.03$ & $110 \pm 2$ & $170 \pm 7$ & $1.86 \pm 0.02$ \\
MgCa3Zn1Gd2 & $-1.48 \pm 0.03$ & $532 \pm 10$ & $51 \pm 2$ & $0.62 \pm 0.02$ \\
MgCa2Zn1Gd3 & $-1.50 \pm 0.03$ & $480 \pm 9$ & $98 \pm 4$ & $1.48 \pm 0.02$ \\
\hline
\end{tabular}

Srinivasan et al. [18] studied the corrosion behaviors of two Mg-10Gd-2Zn and Mg-10Gd-6Zn alloys in $0.5 \mathrm{wt}$. \% NaCl solution. They compared the corrosion parameters after different immersion times, for $0.5,24$, and $100 \mathrm{~h}$. The corrosion potentials obtained for these alloys and immersion times are similar to the $\mathrm{E}_{\mathrm{corr}}$ values measured for the studied alloys. The corrosion potentials for $\mathrm{Mg}-10 \mathrm{Gd}-2 \mathrm{Zn}$ are $-1.551 \mathrm{~V},-1.480 \mathrm{~V}$, and $-1.505 \mathrm{~V}$ after $0.5,24$, and $100 \mathrm{~h}$ of immersion, consequently. While, $\mathrm{E}_{\text {corr }}$ for the Mg-10Gd-6Zn alloy are $-1.495 \mathrm{~V},-1.480 \mathrm{~V}$, and $-1.498 \mathrm{~V}$ after the same immersion times. Moreover, the best values of corrosion current densities were obtained (e.g., $\mathrm{i}_{\text {corr }}$ for Mg-10Gd-6Zn is $65 \mu \mathrm{A} \cdot \mathrm{cm}^{-2}$ after $0.5 \mathrm{~h}$ of immersion, $128 \mu \mathrm{A} \cdot \mathrm{cm}^{-2}$ after $24 \mathrm{~h}$ of immersion and $193 \mu \mathrm{A} \cdot \mathrm{cm}^{-2}$ after $100 \mathrm{~h}$ of immersion).

Hydrogen evolution is an important issue of magnesium corrosion mechanism [20,22,23]. A hydrogen evolution method is an easy and reliable method for measuring and monitoring the corrosion rate of $\mathrm{Mg}$-based alloys. It was firstly described by Song et al. [48]. One of the advantages of this method is a high experimental efficiency with smaller theoretical and experimental errors. The results of immersion tests for the MgCa4Zn1Gd1, MgCa3Zn1Gd2, and MgCa2Zn1Gd3 alloys are presented as the hydrogen evolution volume during $48 \mathrm{~h}$ of immersion (Figure 10). The corrosion products were formed slowly on the surface during the first hour of immersion; the degradation rate of the alloys with 2 and $3 \mathrm{wt}$. \% Gd was slow (Table 4 ). We could assume that after $1 \mathrm{~h}$ of immersion of the studied alloys in the artificial environment the corrosion rates calculated from the hydrogen evolution volume were comparable to the results of polarization data (Table 3).

Table 4. Corrosion rates calculated from the hydrogen evolution volume after 1,8 , and $48 \mathrm{~h}$ of immersion for MgCa5-xZn1Gdx ( $=1,2$, and 3 wt. \%) alloys.

\begin{tabular}{|c|c|c|c|}
\hline Alloy & $\begin{array}{c}\text { Corrosion Rate, } \mathbf{v}_{\text {corr }} \\
\mathbf{m m} \cdot \mathbf{y}^{-1} \\
(\text { after } 1 \text { h) }\end{array}$ & $\begin{array}{c}\text { Corrosion Rate, } \mathrm{v}_{\text {corr }} \\
\mathbf{m m} \cdot \mathbf{y}^{-1} \\
(\text { after } 8 \mathrm{~h})\end{array}$ & $\begin{array}{c}\text { Corrosion Rate, } \mathrm{v}_{\text {corr }} \\
\mathrm{mm} \cdot \mathrm{y}^{-1} \\
(\text { after } 48 \mathrm{~h})\end{array}$ \\
\hline MgCa4Zn1Gd1 & $0.16 \pm 0.03$ & $2.66 \pm 0.02$ & $5.97 \pm 0.02$ \\
\hline MgCa3Zn1Gd2 & $0.10 \pm 0.03$ & $1.14 \pm 0.02$ & $8.22 \pm 0.02$ \\
\hline MgCa2Zn1Gd3 & $0.11 \pm 0.03$ & $1.67 \pm 0.02$ & $6.63 \pm 0.02$ \\
\hline
\end{tabular}


In the case of the MgCa4Zn1Gd1 alloy the corrosion rate, $\mathrm{v}_{\text {corr }}$, reached the highest value of $0.16 \mathrm{~mm} \cdot \mathrm{y}^{-1}$ ( $\mathrm{v}_{\text {corr }}$ based on the $\mathrm{i}_{\text {corr }}$ value was $1.86 \mathrm{~mm} \cdot \mathrm{y}^{-1}$ ); the volume of evolved $\mathrm{H}_{2}$ was $1.1 \mathrm{~mL} \cdot \mathrm{cm}^{-2} \cdot \mathrm{h}^{-1}$. MgCa3Zn1Gd2 alloy was characterized by the lowest corrosion rate, which was $0.10 \mathrm{~mm} \cdot \mathrm{y}^{-1}$ (evolved $\mathrm{H}_{2}$ volume was $0.07 \mathrm{~mL} \cdot \mathrm{cm}^{-2} \cdot \mathrm{h}^{-1}$ ) after $1 \mathrm{~h}$ of immersion and the $\mathrm{v}_{\text {corr }}$ from polarization data was $0.62 \mathrm{~mm} \cdot \mathrm{y}^{-1}$. Similar correlation between corrosion rates and the Gd content in the $\mathrm{Mg}$ alloys was observed after $8 \mathrm{~h}$ of immersion. The $\mathrm{v}_{\text {corr }}$ of the alloys with 1 and $3 \mathrm{wt}$ \% Gd were 1.14 and $1.67 \mathrm{~mm} \cdot \mathrm{y}^{-1}$, consequently (Table 4 ).

After $48 \mathrm{~h}$ of immersion a high dissolution of the $\mathrm{Mg}$ alloys was observed. The $\mathrm{H}_{2}$ volume increased significantly and reached values of $53.11,84.11$, and $65.69 \mathrm{~mL} \cdot \mathrm{cm}^{-2}$ for the MgCa4Zn1Gd1, MgCa3Zn1Gd2, and MgCa2Zn1Gd3 alloys, respectively (Figure 10). The corrosion rate of the alloy with 1 wt. \% Gd content was $5.97 \mathrm{~mm} \cdot \mathrm{y}^{-1}$ and this is an effect of Ca addition and a high volume of $\mathrm{Mg}_{2} \mathrm{Ca}$ secondary phases formation. These intermetallic phases were distributed along grain boundaries and caused grain refinement. The decrease of the grain size leads to the formation of a more dense passive layer, on which the corrosion products are an effective barrier against corrosion process [36]. Two other studied alloys are characterized by an increase of corrosion rates; $\mathrm{v}_{\text {corr }}$ were 6.63 and $8.22 \mathrm{~mm} \cdot \mathrm{y}^{-1}$ for the MgCa2Zn1Gd3 and MgCa3Zn1Gd2 alloys, consequently. Zhang et al. [32] measured a corrosion rate of Mg-9Gd-1Zn-0.6Ca alloy. They reported, similarly as in the case of our investigations, that the tested alloy has a higher corrosion resistance among two other alloys with $0.2 \mathrm{wt}$. \% Ca and without Ca content.

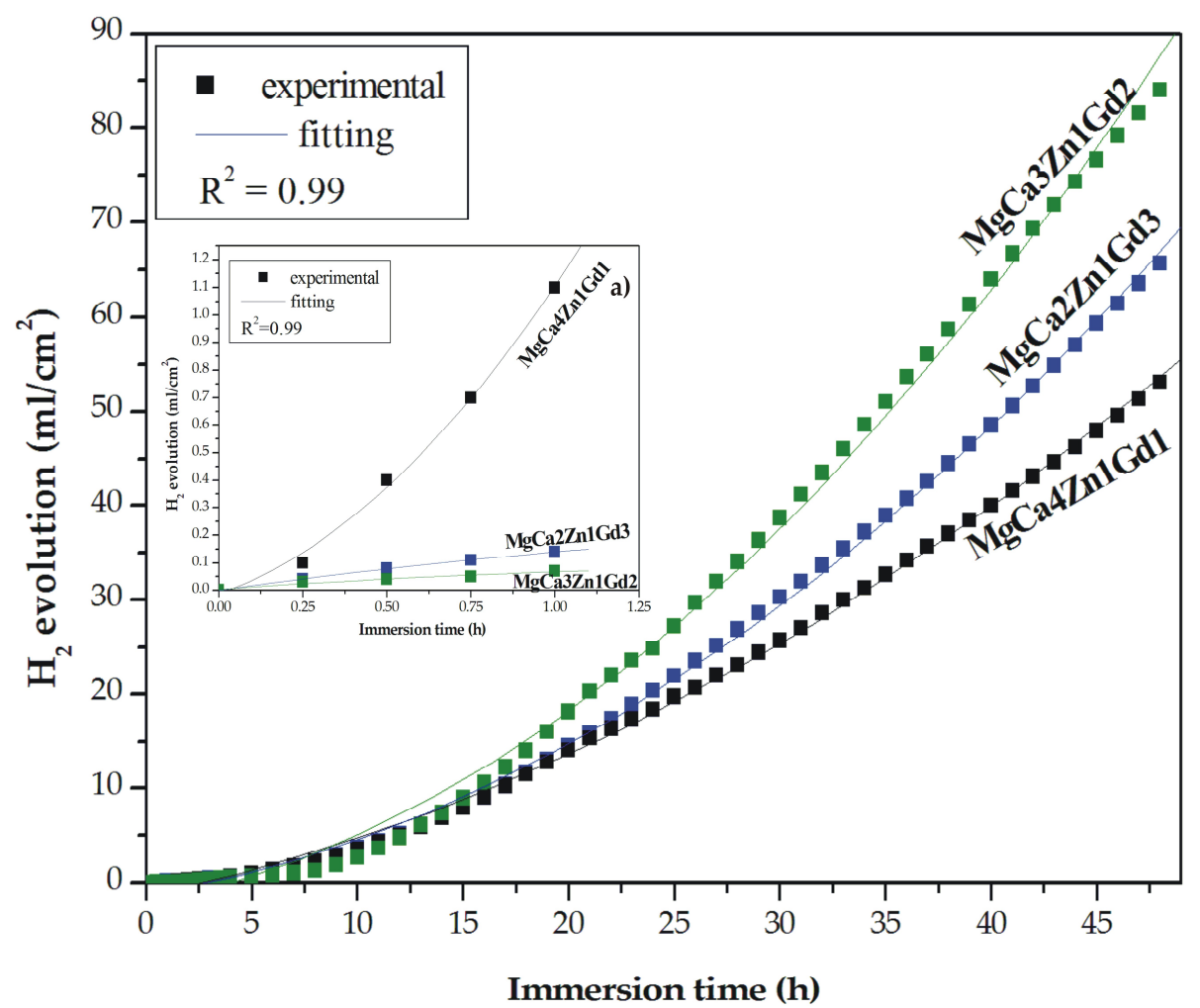

Figure 10. Hydrogen evolution volume as a function of immersion time in Ringer's solution at $37^{\circ} \mathrm{C}$ for studied MgCa5-xZn1Gdx ( $=1,2$, and $3 \mathrm{wt}$. \%) alloys during $48 \mathrm{~h}$ and during $1 \mathrm{~h}$ (a).

The decrease of long term corrosion properties was also noticed by Srinivasan et al. [13]. They carried out the immersion tests in $0.5 \mathrm{wt} . \% \mathrm{NaCl}$ solution during $400 \mathrm{~h}$ for $\mathrm{Mg}-2 \mathrm{Gd}-2 \mathrm{Zn}$, Mg-2Gd-6Zn, Mg-10Gd-2Zn, and Mg-10Gd-6Zn alloys. It was confirmed that an increase of $\mathrm{H}_{2}$ volume for the alloy with $2 \mathrm{wt}$ \% Gd is much lower than that for the alloy with $10 \mathrm{wt}$. \% Gd content. The ternary Mg-10Gd-1.2Ca-0.5Zr alloy in as-cast state examined for 14 days in cell culture medium (CCM) at $37^{\circ} \mathrm{C}$ by Shi et al. [14] is also characterized by a fast corrosion rate. The investigation results 
of an impact of $\mathrm{Mg}$-Gd alloys on a long-term corrosion behavior in $1 \mathrm{wt} . \% \mathrm{NaCl}$ were presented by Hort et al. [49]. They stated that corrosion rates of alloys with $\mathrm{Gd}$ addition are reduced until the gadolinium occurs in solid solution.

The samples surface morphology of the studied alloys after immersion in Ringer's solution for $48 \mathrm{~h}$ is presented in Figure 11. The corrosion products on the surfaces of all Gd-containing alloys were visible. The corroded surface of the MgCa4Zn1Gd1 alloy contained a more dense concentration of corrosion products (Figure 11a). It is in agreement with the long-period hydrogen evolution data.

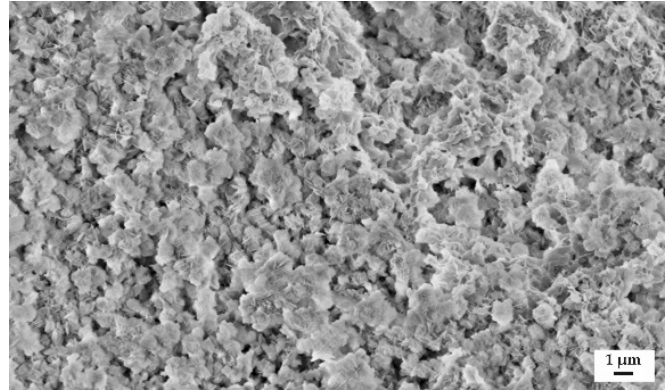

(a)

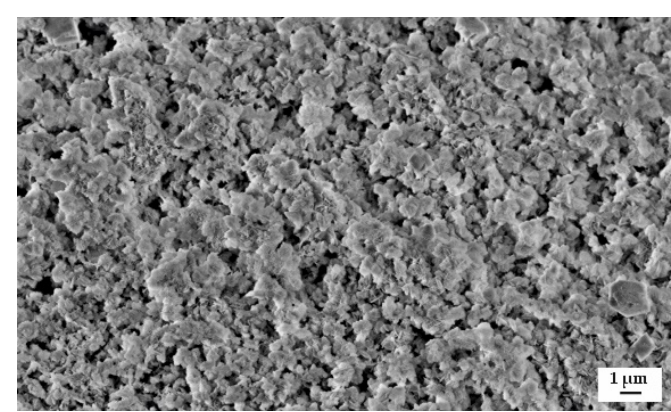

(b)

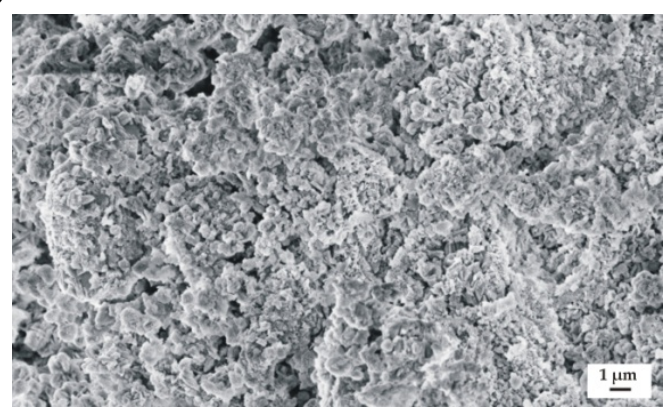

(c)

Figure 11. SEM images of samples' surface with corrosion products of: (a) MgCa4Zn1Gd1; (b) MgCa3Zn1Gd2; and (c) MgCa2Zn1Gd3 alloys after immersion tests in Ringer's solution.

Additionally, the samples surface without corrosion products after $48 \mathrm{~h}$ of immersion was observed using stereoscopic microscope (Figure 12). It can be seen that all $\mathrm{Mg}$ alloys with gadolinium showed the pitting corrosion behaviors. However, the MgCa4Zn1Gd1 and MgCa2Zn1Gd3 alloys exhibited smaller corrosion damages.

The similar corrosion mechanism was also stated by Song et al. [21]. Atrens et al. [19] explained that in chloride solutions (e.g., Ringer's solution) the corrosion appears at breaks in the steady state surface films (consisting of $\mathrm{MgO}$ and $\mathrm{Mg}(\mathrm{OH})_{2}$ films [21]) and chloride ions contribute to form deeper pits.

Based on the experimental results, it could be concluded that MgCa5-xZn1Gdx ( $x=1,2$, and 3 wt. $\%)$ alloys are very interesting and promising biomaterials for potential applications in the human body. Nevertheless, the alloys were characterized by high hydrogen evolution volume, so it is important in the selection of materials for medical implants $\left(\mathrm{H}_{2}\right.$ volume tolerated by human body without hazardous effects for the health is $0.01 \mathrm{~mL} \cdot \mathrm{cm}^{-2}$ per day [50]). The authors intend to improve the long period corrosion results by using protective coatings (e.g., $\mathrm{MgO}$, and $\mathrm{ZnO}$ ) or plastic forming. 


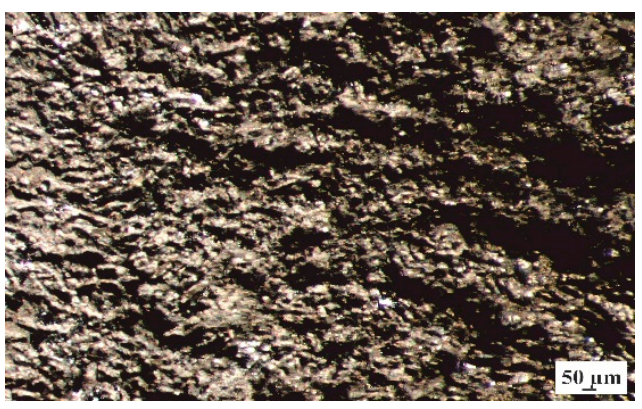

(a)

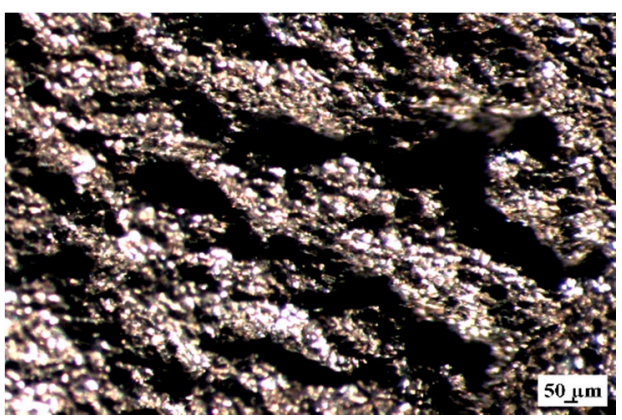

(b)

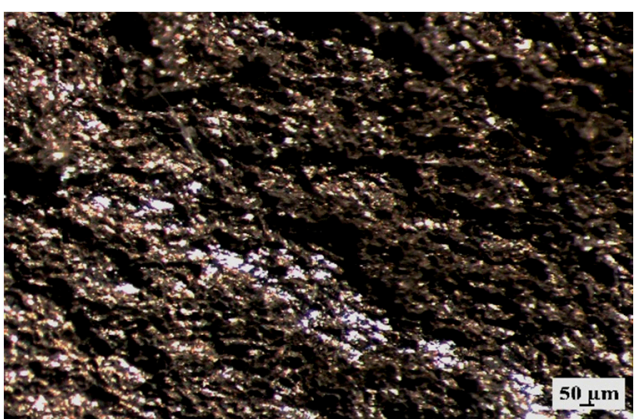

(c)

Figure 12. Stereoscopic images of samples' surface without corrosion products of: (a) MgCa4Zn1Gd1; (b) MgCa3Zn1Gd2; and (c) MgCa2Zn1Gd3 alloys after immersion tests in Ringer's solution.

\section{Conclusions}

1. In the present study the mechanical and corrosion properties of a new designed MgCa5-xZn1Gdx $(\mathrm{x}=1,2$, and $3 \mathrm{wt}$. \%) alloys were presented.

2. The increase of $\mathrm{Gd}$ content in Mg alloys had an effect on the microstructure changes. A small reduction of eutectic volume by a low volume of $\mathrm{Mg}_{2} \mathrm{Ca}$ and $\mathrm{Ca}_{2} \mathrm{Mg}_{6} \mathrm{Zn}_{3}$ secondary phases could be observed.

3. The addition of $\mathrm{Gd}$ in the studied alloys resulted in the improvement of ultimate tensile strength ( $\mathrm{R}_{\mathrm{m}}$ for the alloys with 1,2 , and $3 \mathrm{wt} . \% \mathrm{Gd}$ were 74,78 , and $89 \mathrm{MPa}$, respectively) and a decrease of the elongation (from $4.8 \%$ to $4.2 \%$ ).

4. The increase of $\mathrm{Gd}$ content also improved the compressive properties (for example, the compressive strength, $R_{c}$, were 184, 204, and $221 \mathrm{MPa}$ for the MgCa4Zn1Gd1, MgCa3Zn1Gd2, and MgCa2Zn1Gd3 alloys, consequently).

5. The Vickers hardness increased from 55 to 61 HV1 for the alloys with 1-3 wt. \% Gd.

6. The results of electrochemical corrosion tests showed that the studied alloys were characterized by good corrosion resistance. The corrosion potential ( $\left.\mathrm{E}_{\mathrm{corr}}\right)$ of the alloys shifted towards positive values in comparison to the $\mathrm{E}_{\mathrm{OCP}}$ potential.

7. The electrochemical corrosion rates corresponded with the corrosion rates measured in an aggressive environment during $8 \mathrm{~h}$ with immersion tests. The high corrosion resistance estimated by the evolved $\mathrm{H}_{2}$ volume after 1 and $8 \mathrm{~h}$ of immersion was indicated for the alloy with $2 \mathrm{wt}$. \% Gd. The $\mathrm{v}_{\text {corr }}$ were 0.10 and $1.14 \mathrm{~mm} \cdot \mathrm{y}^{-1}$ for 1 and $8 \mathrm{~h}$, respectively. The corrosion rates changed with time and after $48 \mathrm{~h}$ of immersion, the lowest $\mathrm{v}_{\text {corr }}$ equaled $5.97 \mathrm{~mm} \cdot \mathrm{y}^{-1}$ was noticed for the MgCa4Zn1Gd1 alloy.

Author Contributions: R.N. conceived and designed the experiments; A.G.-M. and A.K. performed the experiments; R.N., R.B. and A.K. analyzed the data; A.K. and R.B. wrote this article. R.N., A.K. and R.B. participated in the revision of the manuscript. All authors had commented on the manuscript.

Funding: This research was funded by the National Science Centre, grant number 2013/09/B/ST8/02129.

Acknowledgments: The authors thank K. Matus, MSc for help in the investigations. 
Conflicts of Interest: The authors declare no conflict of interest.

\section{References}

1. Zhang, E.; Yin, D.; Xu, L.; Yang, L.; Yang, K. Microstructure, mechanical and corrosion properties and biocompatibility of Mg-Zn-Mn alloys for biomedical application. Mater. Sci. Eng. C 2009, 29, 987-993. [CrossRef]

2. Sun, Y.; Zhang, B.; Wang, Y.; Geng, L.; Jiao, X. Preparation and characterization of a new biomedical Mg-Zn-Ca alloy. Mater. Des. 2012, 34, 58-64. [CrossRef]

3. Chen, Y.; Xu, Z.; Smith, C.; Sankar, J. Recent advances on the development of magnesium alloys for biodegradable implants. Acta Biomater. 2014, 10, 4561-4573. [CrossRef]

4. Nowosielski, R.; Bajorek, A.; Babilas, R. Corrosion behavior of bioresorbable Ca-Mg-Zn bulk metallic glasses. J. Non-Cryst. Solids 2016, 447, 126-133. [CrossRef]

5. Xin, Y.; Hu, T.; Chu, P.K. In vitro studies of biomedical magnesium alloys in a simulated physiological environment: A review. Acta Biomater. 2011, 7, 1452-1459. [CrossRef]

6. Nassif, N.; Ghayad, I. Corrosion protection and surface treatment of magnesium alloys used for orthopedic applications. Adv. Mater. Sci. Eng. 2013, 2013, 1-10. [CrossRef]

7. Li, H.F.; Xie, X.H.; Zhao, K.; Wang, Y.B.; Zheng, Y.F.; Wang, W.H.; Qin, L. In vitro and in vivo studies on biodegradable CaMgZnSrYb high-entropy bulk metallic glass. Acta Biomater. 2013, 9, 8561-8573. [CrossRef]

8. Wang, Y.B.; Xie, X.H.; Li, H.F.; Wang, X.L.; Zhao, M.Z.; Zhang, E.W.; Bai, Y.J.; Zheng, Y.F.; Qin, L. Biodegradable CaMgZn bulk metallic glass for potential skeletal application. Acta Biomater. 2011, 7, 3196-3208. [CrossRef] [PubMed]

9. Mareci, D.; Bolat, G.; Izquierdo, J.; Crimu, C.; Munteanu, C.; Antoniac, I.; Souto, R.M. Electrochemical characteristics of bioresorbable binary $\mathrm{MgCa}$ alloys in Ringer's solution: Revealing the impact of local $\mathrm{pH}$ distributions during in-vitro dissolution. Mater. Sci. Eng. C 2016, 60, 402-410. [CrossRef]

10. Gu, X.N.; Zhou, W.R.; Zheng, Y.F.; Cheng, Y.; Wei, S.C.; Zhong, S.P.; Xi, T.F.; Chen, L.J. Corrosion fatigue behaviors of two biomedical Mg alloys - AZ91D and WE43 - in simulated body fluid. Acta Biomater. 2010, 6, 4605-4613. [CrossRef] [PubMed]

11. He, S.M.; Peng, L.M.; Zeng, X.Q.; Ding, W.J.; Zhu, Y.P. Comparison of the microstructure and mechanical properties of a ZK60 alloy with and without 1.3 wt.\% gadolinium addition. Mater. Sci. Eng. A 2006, 433, 175-181. [CrossRef]

12. Vlcek, M.; Cizek, J.; Lukac, F.; Hruska, P.; Smola, B.; Stulikova, I.; Kudrnova, H.; Minarik, P.; Kmjec, T.; Vlasak, T. Hydrogen absorption in Mg-Gd alloy. Int. J. Hydrog. Energ. 2017, 42, 22598-22604. [CrossRef]

13. Srinivasan, A.; Huang, Y.; Mendis, C.L.; Blawert, C.; Kainer, K.U.; Hort, N. Investigations on microstructures, mechanical and corrosion properties of Mg-Gd-Zn alloys. Mater. Sci. Eng. A 2014, 595, 224-234. [CrossRef]

14. Shi, L.; Huang, Y.; Yang, L.; Feyerabend, F.; Mendis, C.; Willumeit, R.; Kainer, K.U.; Hort, N. Mechanical properties and corrosion behavior of Mg-Gd-Ca-Zr alloys for medical applications. J. Mech. Behav. Biomed. Mater. 2015, 47, 38-48. [CrossRef]

15. Zheng, K.Y.; Dong, J.; Zeng, X.Q.; Ding, W.J. Effect of thermo-mechanical treatment on the microstructure and mechanical properties of a Mg-6Gd-2Nd-0.5Zr alloy. Mater. Sci. Eng. A 2007, 454-455, 314-321. [CrossRef]

16. Agarwal, S.; Curtin, J.; Duffy, B.; Jaiswal, S. Biodegradable magnesium alloys for orthopaedic applications: A review on corrosion, biocompatibility and surface modifications. Mater. Sci. Eng. C 2016, 68, $948-963$. [CrossRef]

17. Zheng, Y.F.; Gu, X.N.; Witte, F. Biodegradable metals. Mater. Sci. Eng. R 2014, 77, 1-34. [CrossRef]

18. Srinivasan, A.; Blawert, C.; Huang, Y.; Mendis, C.L.; Kainer, K.U.; Hort, N. Corrosion behavior of Mg-Gd-Zn based alloys in aqueous $\mathrm{NaCl}$ solution. J. Magnes. Alloy. 2014, 2, 245-256. [CrossRef]

19. Atrens, A.; Song, G.L.; Liu, M.; Shi, Z.; Cao, F.; Dargusch, M.S. Review of recent developments in the field of magnesium corrosion. Adv. Eng. Mater. 2015, 17, 400-453. [CrossRef]

20. Song, G.; Atrens, A. Understanding magnesium corrosion mechanism: A framework for improved alloy performance. Adv. Eng. Mater. 2003, 5, 837-858. [CrossRef]

21. Song, G.; Atrens, A. Corrosion mechanisms of magnesium alloys. Adv. Eng. Mater. 1999, 1, 11-33. [CrossRef]

22. Shi, Z.; Liu, M.; Atrens, A. Measurement of the corrosion rate of magnesium alloys using Tafel extrapolation. Corros. Sci. 2010, 52, 579-588. [CrossRef] 
23. Cao, F.; Shi, Z.; Hofstetter, J.; Uggowitzer, P.J.; Song, G.; Liu, M.; Atrens, A. Corrosion of ultra-high-purity Mg in $3.5 \% \mathrm{NaCl}$ solution saturated with $\mathrm{Mg}(\mathrm{OH})_{2}$. Corros. Sci. 2013, 75, 78-99. [CrossRef]

24. Atrens, A.; Johnston, S.; Shi, Z.; Dargusch, M.S. Viewpoint-Understanding Mg corrosion in the body for biodegradable medical implants. Scripta Mater. 2018, 154, 92-100. [CrossRef]

25. Liu, M.; Uggowitzer, P.J.; Nagasekhar, A.V.; Schmutz, P.; Easton, M.; Song, G.; Atrens, A. Calculated phase diagrams and the corrosion of die-cast Mg-Al alloys. Corros. Sci. 2009, 51, 602-619. [CrossRef]

26. Atrens, A.; Song, G.L.; Cao, F.; Shi, Z.; Bowen, P.K. Advances in Mg corrosion and research suggestions. J. Magnes. Alloy. 2013, 1, 177-200. [CrossRef]

27. Zainal Abidin, N.I.; Atrens, A.D.; Martin, D.; Atrens, A. Corrosion of high purity Mg, Mg2Zn0.2Mn, ZE41 and AZ91 in Hank's solution at $37^{\circ}$ C. Corros. Sci. 2011, 53, 3542-3556. [CrossRef]

28. Zainal Abidin, N.I.; Rolfe, B.; Owen, H.; Malisano, J.; Martin, D.; Hofstetter, J.; Uggowitzer, P.J.; Atrens, A. The in vivo and in vitro corrosion of high-purity magnesium and magnesium alloys WZ21 and AZ91. Corros. Sci. 2013, 75, 354-366. [CrossRef]

29. Liu, M.; Zanna, S.; Ardelean, H.; Frateur, I.; Schmutz, P.; Song, G.; Atrens, A.; Marcus, P. A first quantitative XPS study of the surface films formed, by exposure to water, on $\mathrm{Mg}$ and on the $\mathrm{Mg}$ - $\mathrm{Al}$ intermetallics: $\mathrm{Al}_{3} \mathrm{Mg}_{2}$ and $\mathrm{Mg}_{17} \mathrm{Al}_{12}$. Corros. Sci. 2009, 51, 1115-1127. [CrossRef]

30. Chaojie, C.; Cheng, L.; Tong, L.; Cai, Z.; Zhang, H. The effect of Gd and Zn additions on microstructures and mechanical properties of Mg-4Sm-3Nd-Zr alloy. J. Alloy. Compd. 2017, 706, 526-537. [CrossRef]

31. Liu, P.; Jiang, H.; Cai, Z.; Kang, Q.; Zhang, Y. The effect of Y, Ce and Gd on texture, recrystallization and mechanical property of Mg-Zn alloys. J. Magnes. Alloy. 2016, 4, 188-196. [CrossRef]

32. Zhang, X.; Dai, J.; Yang, H.; Liu, S.; He, X.; Wang, Z. Influence of Gd and Ca on microstructure, mechanical and corrosion properties of Mg-Gd-Zn(-Ca) alloys. Mater. Technol. 2017, 32, 399-408. [CrossRef]

33. Hantzsche, K.; Bohlen, J.; Wendt, J.; Kainer, K.U.; Yia, S.B.; Letzig, D. Effect of rare earth additions on microstructure and texture development of magnesium alloy sheets. Scripta Mater. 2010, 63, 725-730. [CrossRef]

34. Gao, L.; Chen, R.S.; Han, E.H. Effects of rare-earth elements Gd and Y on the solid solution strengthening of Mg alloys. J. Alloy. Compd. 2009, 481, 379-384. [CrossRef]

35. Zhang, X.; Ba, Z.; Wang, Z.; He, X.; Shen, C.; Wang, Q. Influence of silver addition on microstructure and corrosion behavior of Mg-Nd-Zn-Zr alloys for biomedical application. Mater. Lett. 2013, 100, 188-191. [CrossRef]

36. Wen, Q.; Deng, K.; Shi, J.; Zhang, B.; Liang, W. Effect of Ca addition on the microstructure and tensile properties of Mg-4.0Zn-2.0Gd alloys. Mater. Sci. Eng. A 2014, 609, 1-6. [CrossRef]

37. Liu, S.J.; Yang, G.Y.; Luo, S.F.; Jie, W.Q. Microstructure and mechanical properties of sand mold cast $\mathrm{Mg}-4.58 \mathrm{Zn}-2.6 \mathrm{Gd}-0.18 \mathrm{Zr}$ magnesium alloy after different heat treatments. J. Alloy. Compd. 2015, 644, 846-853. [CrossRef]

38. Yang, G.; Luo, S.; Liu, S.; Xiao, L.; Jie, W. Microstructural evolution, phase constitution and mechanical properties of directionally solidified Mg-5.5Zn-xGd ( $\mathrm{z}=0.8,2.0$, and 4.0) alloys. J. Alloy. Compd. 2017, 725, 145-154. [CrossRef]

39. Fei, S.H.I.; Wang, C.Q.; Zhang, Z.M. Microstructures, corrosion and mechanical properties of as-cast Mg-Zn-Y-(Gd) alloys. Trans. Nonferrous Met. Soc. China 2015, 25, 2172-2180. [CrossRef]

40. Liu, M.; Qiu, D.; Zhao, M.C.; Song, G.; Atrens, A. The effect of crystallographic orientation on the active corrosion of pure magnesium. Scripta Mater. 2008, 58, 421-424. [CrossRef]

41. Myrissa, A.; Agha, N.A.; Lu, Y.; Martinelli, E.; Eichler, J.; Szakács, G.; Kleinhans, K.; Willumeit-Römer, R.; Schäfer, U.; Weinberg, A.M. In vitro and in vivo comparison of binary Mg alloys and pure Mg. Mater. Sci. Eng. C 2016, 61, 865-874. [CrossRef]

42. ISO. Metallic Materials_Tensile Testing_Part 1: Method of Test at Room Temperature; ISO 6892-1:2016; ISO: Geneva, Switzerland, 2016.

43. Static Compression Test of Metallic Materials; PN-H-04320:1957; Polish Committee for Standardization: Warsaw, Poland, 1957. (In Polish)

44. Hiraga, K.; Ohsuna, T.; Yasuda, K.; Sugiyama, K. The structures of hexagonal phases in Mg-Zn-RE (RE = Sm and Gd) alloys. Z. Krist. 1998, 213, 537-543. [CrossRef]

45. Li, Y.; Qin, F.; Liu, C.; Wu, Z. A review: Effect of friction stir welding on microstructure and mechanical properties of magnesium alloys. Metals 2017, 7, 524. [CrossRef] 
46. Min, Y.; Debao, L.; Runfang, Z.; Minfang, C. Microstructure and properties of Mg-3Zn-0.2Ca alloy for biomedical application. Rare Met. Mater. Eng. 2018, 47, 93-98. [CrossRef]

47. Zainal Abidin, N.I.; Martin, D.; Atrens, A. Corrosion of high purity Mg, AZ91, ZE41, and Mg2Zn0.2Mn in Hank's solution at room temperature. Corros. Sci. 2011, 53, 862-872. [CrossRef]

48. Song, G.L.; Atrens, A.; StJohn, D. An hydrogen evolution method for the estimation of the corrosion rate of magnesium alloys. Mag. Technol. 2001, 255-262.

49. Hort, N.; Huang, Y.; Fechner, D.; Störmer, M.; Blawert, C.; Witte, F.; Vogt, C.; Drücker, H.; Willumeit, R.; Kainer, K.U.; et al. Magnesium alloys as implant materials - Principles of property design for Mg-RE alloys. Acta Biomater. 2010, 6, 1714-1725. [CrossRef]

50. Zeng, R.C.; Dietzel, W.; Witte, F.; Hort, N.; Blawert, C. Progress and challenge for magnesium alloys as biomaterials. Adv. Eng. Mater. 2008, 10, B3-B14. [CrossRef]

(C) 2019 by the authors. Licensee MDPI, Basel, Switzerland. This article is an open access article distributed under the terms and conditions of the Creative Commons Attribution (CC BY) license (http://creativecommons.org/licenses/by/4.0/). 